\title{
Greening Manufacturing Supply Chains - Introducing Bio-based Products into Manufacturing Supply Chains
}

\author{
David Sparling ${ }^{1}$, Fred Pries ${ }^{2}$, and Erin Cheney ${ }^{1}$ \\ ${ }^{1}$ The Richard Ivey School of Business, London, Canada \\ \{dsparling, echeney\} @ivey.ca \\ ${ }^{2}$ University of Guelph, Guelph, Canada \\ fpries@uoguelph.ca
}

\begin{abstract}
Launching a new technology involves more than innovation within an organization. It often requires innovations in downstream firms adopting the technology and greater interaction and knowledge exchange among supply chain partners. This paper examines the introduction of new bio-based products into existing supply chains, the location of the innovations needed to successfully commercialize the product, the nature of relationships among chain members and the impact of modularization on bio-based product introductions.
\end{abstract}

Keywords: supply chain, modularity, innovation, bioproducts.

\section{Introduction}

The major challenges in introducing new or redesigned products are often associated with consumer acceptance. The situation is different for bio-based industrial products, where the main impacts are on companies rather than consumers and the motivations are reducing costs, oil consumption and the environmental impact of manufacturing processes and products. The main challenge is often adoption by supply chain members. Adoption may require significant innovation among supply chain partners, with greater interaction and exchange of knowledge through the chain. Success may also depend on the knowledge partners supporting the innovations through research, development and design.

An early outcome of the bio-based economy has been the construction of ethanol supply chains and investment in the capital intensive infrastructure to support them. Manufacturing supply chains are longer than fuel chains and involve more partners and products. New bio-based chemicals can often link to existing manufacturing chains, greatly reducing the investment needed to create more sustainable manufacturing chains.

This study investigates the process of greening manufacturing supply chains viewed through the lens of supply chain modularity, where inserting a bio-based chemical module (or company) into a chain can change the environmental and financial performance of the entire manufacturing chain. The study examines the innovations required to commercialize the new technologies, the location of those innovations within the chains and the nature and evolution of the interactions between innovating organizations and their supply chain partners. 


\section{Literature}

Concerns over the environment and energy have moved bio-based products higher on the strategic agendas of industrial supply chains. The chemical industry in particular, offers great potential for bio-based alternatives. In 2009, global chemical industry sales (excluding pharmaceuticals) were valued at about US\$2.61 trillion (ICCA Review, 2009-2010). Revenue potential for what King (2010) terms "biorefinery-based chemicals" is estimated at US\$ 10-15-billion by 2020 and projected to represent $8 \%$ of global chemical sales in 2012 (ICIS, 2010). Many different areas of science and technology overlap in bio-based chemicals creating a highly complex industry (Chotani (2000), Lorenz (2002)). While the current landscape consists primarily of smaller new bio-based technology companies, interest is growing among multinationals (King, 2010).

Although past focus was generally on innovation strategies within the firm, there is a growing recognition that successful innovation also depends on the actions taken by customers and suppliers. Adner and Kapoor (2009) characterize the innovation environment faced by companies as an ecosystem, where the success of an innovation depends, not only on the innovation strategies internal to the firm, but also on innovations within a firm's supply chain. They hypothesized that value creation and capture depend on the position of necessary innovations relative to the focal firm.

Innovation in business models and industry structure is as important for a sector as scientific innovation (Pisano, 2006). Baldwin and Clark (2000) and Jacobides et al. (2006) identify that industry participants can strategically re-engineer industry architecture through investment in platform technologies and Pisano and Teece (2007) argue that changes to industry architecture is one of two critical domains where value can be captured from innovation.

The theory of modularity, based on design theories of Herbert Simon (1969), Christopher Alexander (1964) and recent work by Baldwin (2007), provides one lens with which to examine the introduction of bio-based technologies and products into traditional manufacturing supply chains. Commercializing some inventions may involve the simple substitution of a link in the supply chain ('drop-in' innovations), while others may require adaptation by many organizations in the supply chain. The ease with which substitutions can occur may be dependent on the modularity of the supply chain. Baldwin and Clark (2000) define a module as a group of tasks that are highly interrelated within the module but are only marginally related to tasks in other modules. Baldwin (2007) identifies and characterizes thick and thin crossing points in supply chains, suggesting thin crossing points have few, relatively simple transfers of material, energy and information and often occur between modules. Thick crossing points have numerous and/or complex transfers, high-transaction costs and can be associated with opportunistic behavior (Baldwin, 2007). The design of transactions and relationships differs systematically with the thickness of the crossing points. Spot transactions are more likely at thin crossing points, while vertical integration or formal and relational contracts designed to reduce transactions costs are more common at thicker ones. 
Many of the theories on innovation, modularity and supply chains were developed in the computer industry. Bioproduct innovation differs on several dimensions. The products have longer life cycles, the objectives include greener supply chains and replacing oil, and supply chain partners include farmers and forestry companies. This study extends the concepts introduced by Adner and Kapoor (2009) to the bioproduct industry and particularly bio-based chemicals, examining how the nature and location of innovations affect the commercialization process for bio-based chemical innovations. It applies Baldwin's theories on the thickness of crossing points to innovation relationships in bio-based supply chains and adds consideration of timing to the discussion on modularity.

\section{Methods}

A case study approach was employed to study innovation in four supply chains developing new bio-based products (Figure 1). The research addressed the following hypotheses:

- H1: Introduction of a new bio-based substitute for an existing oil-based component will be more likely to succeed where the production of the bio-based substitute occurs in a highly modular organization with thin crossing points to existing supply chains and few innovations needed in the rest of the chain.

- H2: The nature of modules changes as technologies are developed. Innovating organizations must incorporate more transactions and organizations during the early stages of development of a new bio-based technology than at later stages and will exhibit differences in the thickness of its crossing points at different stages.

- H3: Introduction of a bio-based substitute will be more successful if the innovations needed to commercialize the product are located adjacent to the focal firm.

Background data for the case studies was collected using publicly available data. More detailed information on the companies was collected through semi-structured interviews with selected industry participants holding senior management positions.

\section{$4 \quad$ Results}

Three chains involved new to the industry bio-based chemicals and the fourth involved a bio-fibre composite material. The research found that bio-based chemical chains were typically composed of 'traditional' technology firms, with a single biofocused firm which acted as the link between biomass production and traditional economy firms (Figure 1). The motivations for adopting bio-based products differed. For some chains the motivation was to produce more environmentally friendly products for end consumers (Chains 1 and 2). In other cases, the motivation was reducing costs (Chains 2 and 4) or supply uncertainty (Chain 3). In each chain, reducing the environmental impacts of the manufacturing processes provided an additional incentive but, by itself, sustainability did not motivate adoption. 

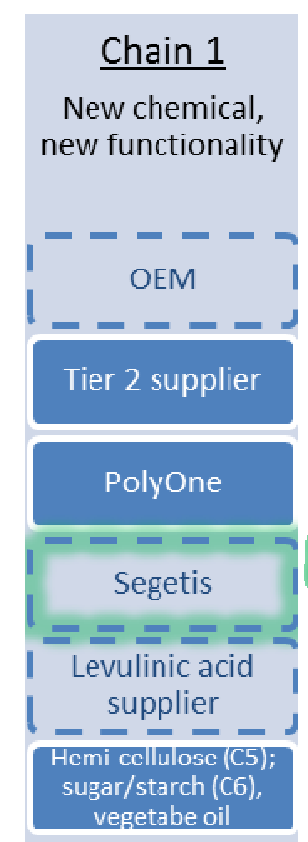

I-- Missing link
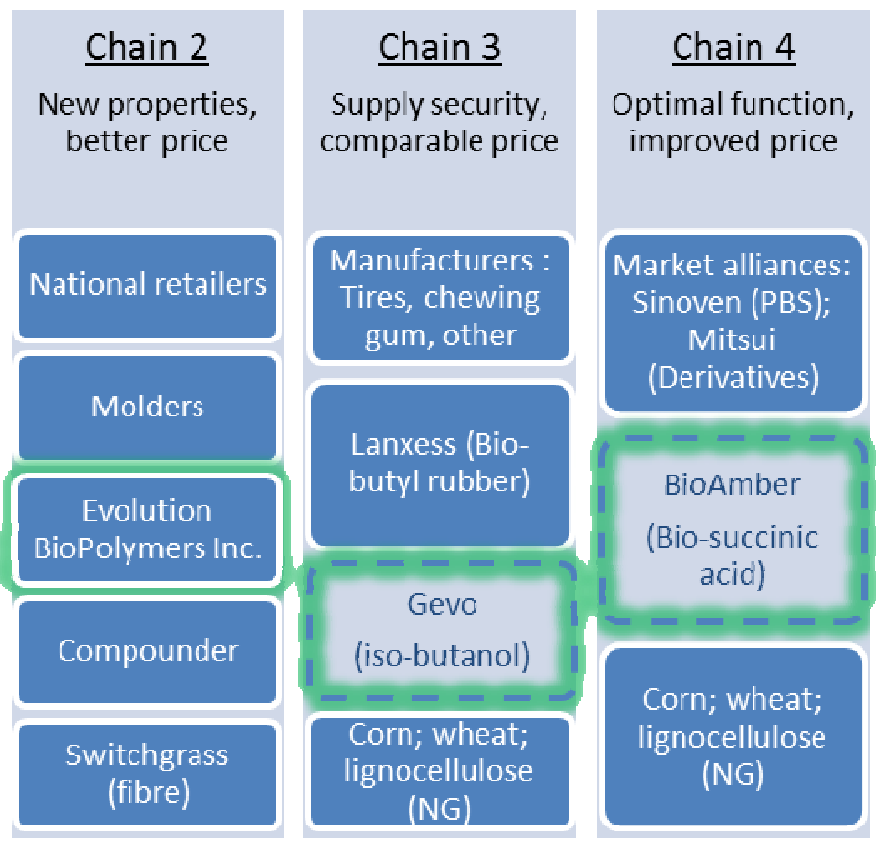

New economy bio-based

Old economy bio-shift

Fig. 1. Bio-based chemical supply chains

NG: Next Generation (planned)

Converting an oil-based manufacturing chain to a bio-based alternative involves two distinct sets of innovation activities. The first is primarily internal, developing bio-based substrates and adapting them to the particular needs of the chemical and manufacturing partners. The second requires innovations external to the focal firms. In the chains examined, innovations were primarily among downstream supply chain members and involved them making the process and/or product innovations needed to incorporate the bio-based alternatives. Their products often served as inputs to downstream firms, making further downstream adaptation necessary in some cases.

The location of required innovations mattered. In two of the supply chains (chains $3 \& 4$ ), the innovations required were primarily internal, as their products could act as direct substitutes for the oil-based products used by customers (Figure 2). In chain 1 the bio-based module, Segetis, introduced a new compound which required changes to the product formulations in the two subsequent downstream organizations, but not to the OEM at the end of the chain. Although the new bio-based chemical provided greater functionality, it did so at a higher cost and with more switching costs for other members of the chain. This chain has had the most significant challenges in commercializing their innovation. Chain 2 exhibited both complement (upstream) and component (downstream) challenges but because the innovations needed were in firms adjacent to the innovating firm, the challenges were more easily overcome. 


\section{External complement challenges}

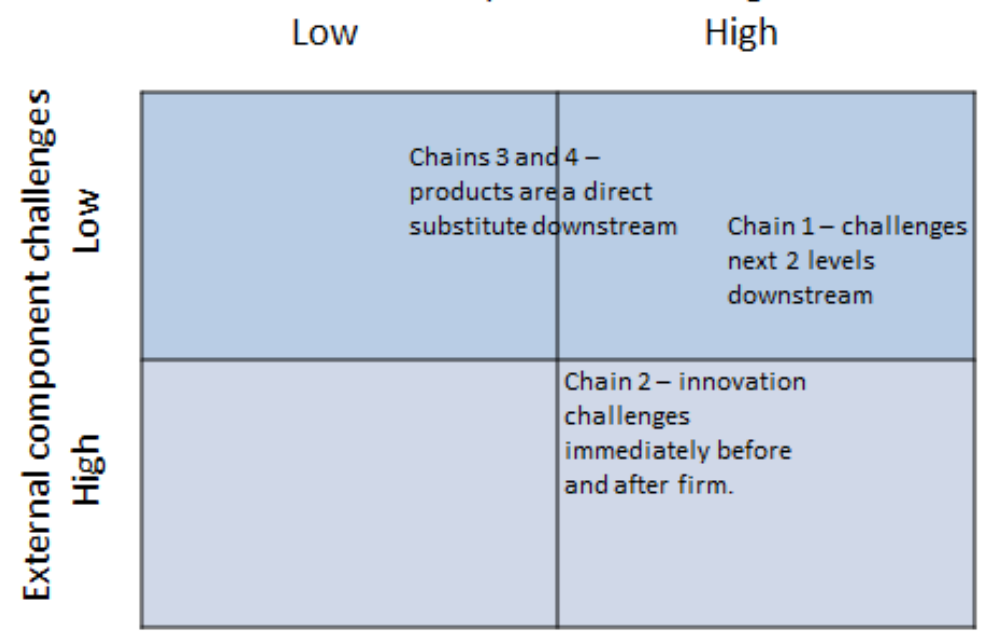

Fig. 2. Location of necessary supply chain innovations (adapted from Adner and Kapoor, 2009)

The location of the innovation challenges is important; so too is the location of the knowledge and technologies needed to overcome those challenges. Chain 2 represents a particularly interesting example of how modules adapt during development, expanding to incorporate additional capabilities needed to commercialize a new technology. The innovation was a bio-composite plastic made of switchgrass and recycled plastic for use in manufacturing small bins for hardware and small tools. A knowledge partner, a university research group external to the supply chain, was critical to commercializing the technology. The research group created different formulations for the innovating firm to test upstream with the compounder producing the bio-composite and downstream with the extruder partner manufacturing bins from the biomaterial. Fifty formulations were tested over 14 months leading to the successful launch of biobins in major retailers in Canada. Government funding supported the laboratory research, reducing transactions costs for the innovating company. Sole sourcing agreements and shared product development reduced transactions costs for the compounder, the innovating company and the downstream extrusion firm manufacturing the containers. The finished product was a direct substitute for existing plastic bins but provided retailers with a greener product offering higher margins.

The nature of the interaction between the bio-based modules and chemi$\mathrm{cal} /$ manufacturing supply chains is explored in Table 1 . The modularity of the four chains was assessed by examining the costs and nature of transactions at the points where traditional economy firms interfaced with bio-modules. Overall findings were generally consistent with predictions of modularity theory. In some cases, the interactions represent thick crossing points with significant knowledge and process interactions and higher transaction costs. Thick crossing points where characterized by greater market and technology uncertainty and generally resulted in the need for more 
formal contractual relationships. At thin crossing points, lower transaction costs and knowledge interactions were required to commercialize the new bio-chemical products. Thin crossings were also associated with less formal contracts using spot market pricing and supply contracts. Thick crossing points were seen more in downstream relationships then upstream, where knowledge of the new biomaterial had to be passed between modules or where skills had to be temporarily incorporated to assist in commercialization, as discussed above.

Table 1. Interaction between the bioproduct innovator and the existing supply chain

\begin{tabular}{|c|c|c|c|c|}
\hline & Case 1 & Case 2 & Case 3 & Case 4 \\
\hline Innovator & Segetis & $\begin{array}{l}\text { Evolution } \\
\text { Biopolymers }\end{array}$ & Gevo & BioAmber \\
\hline Product & $\begin{array}{l}\text { L-ketal - Unique } \\
\text { chemical from } \\
\text { levulinic acid } \\
\text { and glycerol }\end{array}$ & $\begin{array}{l}\text { A biocomposite } \\
\text { of up to } 30 \% \\
\text { natural fibre and } \\
\text { recycled plastic }\end{array}$ & $\begin{array}{l}\text { Platform tech- } \\
\text { nology for pro- } \\
\text { ducing bio-based } \\
\text { iso-butanol }\end{array}$ & $\begin{array}{l}\text { A bio-based } \\
\text { succinic acid } \\
\text { and its deriva- } \\
\text { tives such as } \\
\text { PBS and BDO }\end{array}$ \\
\hline $\begin{array}{l}\text { Key product } \\
\text { features }\end{array}$ & $\begin{array}{l}\text { Improved func- } \\
\text { tionality as sol- } \\
\text { vent, polyol, } \\
\text { plasticizer } \\
\end{array}$ & $\begin{array}{l}\text { Lower cost, } \\
\text { more strength } \\
\text { and "green" } \\
\text { footprint }\end{array}$ & $\begin{array}{l}\text { Competitively } \\
\text { priced iso- } \\
\text { butanol }\end{array}$ & $\begin{array}{l}\text { Low cost re- } \\
\text { placement - bio- } \\
\text { succinic acid }\end{array}$ \\
\hline \multicolumn{5}{|c|}{ IMPACT ON DOWNSTREAM SUPPLY CHAIN } \\
\hline $\begin{array}{l}\text { Knowledge } \\
\text { user \& pro- } \\
\text { ducer must } \\
\text { have about the } \\
\text { other's domain }\end{array}$ & $\begin{array}{l}\text { Very high. New } \\
\text { molecule re- } \\
\text { quires } \\
\text { knowledge shar- } \\
\text { ing with user. }\end{array}$ & $\begin{array}{l}\text { Limited. Bio- } \\
\text { composite resin } \\
\text { must work in } \\
\text { existing molding } \\
\text { processes. }\end{array}$ & $\begin{array}{l}\text { High. Exchange } \\
\text { supports advanc- } \\
\text { es in chemistry } \\
\text { and market for } \\
\text { iso-butanol. }\end{array}$ & $\begin{array}{l}\text { Very limited. } \\
\text { Bio-succinic } \\
\text { acid is identical } \\
\text { to petroleum } \\
\text { derived succinic } \\
\text { acid. }\end{array}$ \\
\hline Crossing pt & Thick & Thin & Thick & Thin \\
\hline $\begin{array}{l}\text { Nature of } \\
\text { transaction } \\
\text { between par- } \\
\text { ties }\end{array}$ & $\begin{array}{l}\text { Long-term sup- } \\
\text { ply \& joint de- } \\
\text { velopment } \\
\text { agreements. }\end{array}$ & Purchase order & $\begin{array}{l}\text { Long-term sup- } \\
\text { ply agreements } \\
\text { for iso-butanol. }\end{array}$ & $\begin{array}{l}\text { Exclusive and } \\
\text { long-term sup- } \\
\text { ply agreements, } \\
\text { joint develop- } \\
\text { ment. }\end{array}$ \\
\hline $\begin{array}{l}\text { Transaction } \\
\text { costs }\end{array}$ & High & Low & Moderate & Low \\
\hline $\begin{array}{l}\text { Strategies to } \\
\text { reduce down- } \\
\text { stream trans- } \\
\text { action costs }\end{array}$ & $\begin{array}{l}\text { Joint develop- } \\
\text { ment agree- } \\
\text { ments. }\end{array}$ & $\begin{array}{l}\text { Government } \\
\text { funded R\&D } \\
\text { center. Exclu- } \\
\text { sive downstream } \\
\text { relationships. }\end{array}$ & $\begin{array}{l}\text { Investment from } \\
\text { major customer. }\end{array}$ & $\begin{array}{l}\text { Investment from } \\
\text { customer. }\end{array}$ \\
\hline
\end{tabular}


Table 1. (continued)

\begin{tabular}{|c|c|c|c|c|}
\hline \multicolumn{5}{|c|}{ IMPACT ON UPSTREAM SUPPLY CHAIN } \\
\hline $\begin{array}{l}\text { Knowledge } \\
\text { user \& pro- } \\
\text { ducer must } \\
\text { have about the } \\
\text { other's domain }\end{array}$ & $\begin{array}{l}\text { Limited. User } \\
\text { assured of a five- } \\
\text { carbon sugar } \\
\text { which has been } \\
\text { difficult to } \\
\text { source. }\end{array}$ & Very high. & $\begin{array}{l}\text { Very limited. } \\
\text { GEVO technolo- } \\
\text { gy will retrofit } \\
\text { any ethanol } \\
\text { plant. }\end{array}$ & $\begin{array}{l}\text { Very limited. } \\
\text { Feedstock is } \\
\text { sugar (in six } \\
\text { carbon form) } \\
\text { and carbon } \\
\text { dioxide. }\end{array}$ \\
\hline Crossing pt & Thin & Thick & Thin & Thin \\
\hline $\begin{array}{l}\text { Nature of } \\
\text { transaction } \\
\text { between par- } \\
\text { ties }\end{array}$ & $\begin{array}{l}\text { Limited supply } \\
\text { difficult sourc- } \\
\text { ing; relational } \\
\text { contract may } \\
\text { ensure supply. }\end{array}$ & $\begin{array}{l}\text { Long term sup- } \\
\text { ply, exclusive } \\
\text { supplier ar- } \\
\text { rangements for } \\
\text { biomass. }\end{array}$ & $\begin{array}{l}\text { Long term sup- } \\
\text { ply contracts, } \\
\text { spot markets (as } \\
\text { needed). }\end{array}$ & $\begin{array}{l}\text { Long term sup- } \\
\text { ply contracts, } \\
\text { spot markets as } \\
\text { needed. }\end{array}$ \\
\hline $\begin{array}{l}\text { Transaction } \\
\text { costs }\end{array}$ & Low & Moderate & High & Low \\
\hline $\begin{array}{l}\text { Strategies } \\
\text { used to reduce } \\
\text { upstream } \\
\text { transaction } \\
\text { costs }\end{array}$ & $\begin{array}{l}\text { Consideration to } \\
\text { back integrate } \\
\text { into feedstock } \\
\text { production. }\end{array}$ & $\begin{array}{l}\text { Sole sourcing } \\
\text { with upstream } \\
\text { supplier. }\end{array}$ & $\begin{array}{l}\text { Vertical integra- } \\
\text { tion upstream. }\end{array}$ & $\begin{array}{l}\text { Co-location of } \\
\text { new production } \\
\text { facilities with } \\
\text { major develop- } \\
\text { ment partner. }\end{array}$ \\
\hline
\end{tabular}

Although the sample size was limited, the results affirmed H1: innovations which required fewer innovations in other firms in the supply chain were more likely to succeed. This was the case in chains 2 through 4 which were moving to successful commercialization, while chain 1 was challenged by the downstream innovations needed in the succeeding two levels. The focal firm had to deal with uncertainties of feedstock supply, in addition to the marketing and sale of a new chemical molecule that was heavily dependent on third party partners and downstream collaborators to show proof of concept at all levels of the supply chain.

Chains 2, 3 and 4 also provided confirmation for $\mathrm{H} 2$ : each exhibited much broader modules during development, incorporating more transactions and organizations than were planned for or needed after development was completed. The innovating firm in chain 3 used vertical integration to reduce transactions costs downstream while investments by governments helped reduce transactions costs in chains 2 and 4 . Both chains 2 and 3 planned to reduce their module scope once development was completed, changing their downstream crossings from thick to thin.

Results also affirmed H3: introduction of bio-based alternatives is most successful when innovations required for commercialization are located near or within the focal firm. In chain 2 , the innovations required were immediately before the innovating firm and were managed during development through shared development and government support for knowledge partners. In chain 3, the innovations needed were immediately upstream, modifying an ethanol plant, and downstream, encouraging buyers to switch. The innovating firm expanded their module, vertically integrating backward during development to control the integration of their processes with 
ethanol production. Once the technology and processes are fully understood and stable the innovator will refocus, concentrating solely on the iso-butanol modules which can be sold or licensed to ethanol facilities. Chain 1 is a good example of how required innovations further downstream can challenge innovating companies.

\section{Conclusion}

The supply chains studied all illustrated the application of modularity theory to the introduction of bio-based technologies into traditional manufacturing chains. Rather than constructing entirely new chains, bio-based modules were integrated into existing chains but that integration was influenced, at least in part, by the nature and location of downstream innovations needed to commercialize the new technologies. The structure and transactions in the module and thickness of its crossing changed during development as innovation challenges were resolved. Solving the upstream and downstream innovation challenges required a relationship between the innovation process and the production processes and systems in the existing supply chains. It was also dependent on the role of partners with external knowledge.

\section{References}

1. Adner, R., Kapoor, R.: Value creation in innovation ecosystems: how the structure of technological interdependence affects firm performance in new technology generations. Strategic Management Journal 31, 306-333 (2009)

2. Alexander, C.: Notes on the synthesis of Form. Harvard University Press, Cambridge (1964)

3. Baldwin, C.L.: Where do transactions come from? Modularity, transactions, and the boundaries of firms. Industrial and Corporate Change 17, 155-195 (2007)

4. Chotani, G., et al.: The commercial production of chemicals using pathway engineering. Biochim. Biophys. Acta Mol. Cell Res. 1543, 434-455 (2000)

5. ICCA Review (2009-2010), http: / / www. icca-chem. org/ICCADocs / ICCA-review-2009-2010.pdf

6. ICIS (2010), http://www.icis.com/cgi-bin/mt/ mt-search.cgi ? search=McKinsey\&IncluldeBlogs $=148 \& l i m i t=20$

7. Jacobides, M.G., Billinger, S.: Designing the boundaries of the firm: from "make, buy or ally" to the dynamic benefits of vertical architecture. Organization Science 17(2), 249-261 (2006)

8. King, D.: The Future of Industrial Biorefineries. World Economic Forum, Cologny/Geneva (2010)

9. Lorenz, P., et al.: Screening for novel enzymes for biocatalytic processes: accessing the metagenome as a resource of novel functional sequence space. Curr. Opin. Biotechnol. 13, 572-577 (2002)

10. Pisano, G.: Profiting from innovation and the intellectual property revolution. Research Policy 35, 1122-1130 (2006)

11. Pisano, G., Teece, D.: 'How to capture value from innovation: shaping intellectual property and industry architecture'. California Management Review 50(1), 278-296 (2007)

12. Simon, H.A.: The Science of the Artificial. MIT Press, Cambridge (1969) 